\title{
Gyomflóra és biomassza produkció vizsgálatok trágyázási tartamkísérletben a kukorica korai fenológiai stádiumában
}

\author{
${ }^{1 *}$ MAZSU Nikolett, ${ }^{1}$ KAMUTI Mariann, ${ }^{1}$ SÁNDOR Renáta, ${ }^{2}$ SZENTES Dóra és ${ }^{1}$ LEHOCZKY \\ Éva \\ ${ }^{1}$ MTA Agrártudományi Kutatóközpont, Talajtani és Agrokémiai Intézet, Budapest \\ ${ }^{2}$ NÉBIH, Növény-, Talaj- és Agrárkörnyezet-védelmi Igazgatóság, Budapest
}

\section{Bevezetés}

Jelenleg az ország területének mintegy 47\%-át müvelik szántóterületként (KSH, 2016), mely jelentős komparatív előnyhöz juttatja Magyarországot. Szántóföldi növények közül a kukorica és a búza vetésterülete meghatározó, amelyek a 20112015 közötti időszak átlagában 1,2 millió, ill. 1,1 millió ha területet képviseltek. Ezért is jelentős, hogy ismereteinket bővítsük a fenntartható mezőgazdasági termelés és termelékenység fejlesztése céljából, amelyet egyre szélsőségesebb környezeti feltételek mellett kell teljesíteni (SENGAR \& SENGAR, 2015; TAMÁs et al., 2015). A várható termés, ill. biomassza produkció szempontjából a klíma faktor (pl.: aszály, szélsőséges csapadékeloszlás) mellett a gyomosodásnak, ill. járulékos hatásainak [víz- és tápanyag felvétel (LEHOCZKY et al., 2016)] jelentős szerepe van a kukorica kultúrában (KANG et al., 2009; OLESEN et al., 2011).

A kukorica - mint a legtöbb tág térállású kultúrnövény - rendkívül érzékeny a gyomkompetícióra (BERZSENYI et al. 1993; RAJCAN \& SWANTON, 2001), amely jelentős biomassza csökkenést (LEHOCZKY et al., 2005) és termés kiesést (YEGANEHPOOR et al., 2015) eredményezhet, így csökkentve agrárterületeink termelési hatékonyságát és versenyképességét, ezért a megfelelö gyomszabályozás kulcsfontosságú. A kukoricatermesztés másik sarkalatos pontja a szakszerü tápanyagellátás, a makro-, mezo-, és mikroelemek optimális arányú biztosítása (ANTAL, 1987; LÁSZTITY \& CSATHÓ, 1994). A kultúrnövények igényével kapcsolatban jól körülhatárolt információk állnak rendelkezésre, faj és fajta vonatkozásában is. Azonban, az egyes gyomnövény fajok esetében már jóval kevesebb ismeret áll rendelkezésünkre (NAGY \& TAMÁs, 2013). Az azonban bizonyos, hogy a különböző gyomnövény fajok tápanyagigénye, tápanyagokért folytatott versengése, valamint eltérő tápanyag-ellátottsági szintekhez való alkalmazkodó képessége igen változatos (LEHOCZKY, 2004a). Például, az ürömlevelü parlagfü (Ambrosia artemisiifolia L.), amely az elmúlt 20 évben a szántóföldi gyomnövények fontossági sorrendjében az első volt az országos gyomfelvételezések alapján, nem igényes a talaj tápanyagellátottsági szintjére. Ezzel szemben a fehér libatop (Chenopodium album L.; 3. legfontosabb gyomfaj), ill. a csattanó maszlag (Datura stramonium L.; 9. legfontosabb gyomfaj) a tápanyagban gazdag talajokban fordulnak elő nagyobb gyakorisággal (NoVÁK et al., 2011).

Postai cím: MAZsu NiKOLETT, MTA ATK TAKI, 1022 Budapest, Herman Ottó út 15.

E-mail: mazsu.nikolett@agrar.mta.hu 
Az okszerü növénytáplálás segíti a kultúrnövény fejlődését, stressz türését és kompetíciós képességét, azonban egyes esetekben a tápanyag utánpótlás a gyomok fejlődését ennél is nagyobb mértékben serkenti (LEHOCZKY et al., 2007). HUNYADI (1988) szerint a nitrogén növeli a kultúrnövények árnyékoló képességét. Ezzel visszaszoríthatjuk a fénykedvelö fajok részarányát, mialatt kedvező körülményeket biztosíthatunk árnyéktürő gyomnövényeknek (pl. Chenopodium album L.).

A gyomok fajgazdagsága és alkalmazkodóképessége a környezeti körülményekhez elősegíti széleskörủ elterjedésüket mind tápanyagszegény, mind a jól ellátott területeken (YIN et al., 2006; KAMUTI et al., 2015). A kultúrnövénnyel szemben a szélesebb gyomspektrumból olyan fajok indulnak erőteljesebb fejlődésnek, amelyek leginkább hasznosítani képesek a rendelkezésre álló forrásokat (KÁDÁR et al., 1999).

A szántóföldi kultúrákban elterjedt gyomfajok erős alkalmazkodó képességgel rendelkeznek, így - különösen a kukorica korai fenológiai fázisaiban - a tápanyagokért és vízért folyó versenyben a kultúrnövény fölé kerekedhetnek (LEHOCZKY et al., 2016). Ezért is kiemelkedően fontos a gyomnövények diverzitásának és biomassza produkciójának a tápanyag-ellátottsággal összefüggésben történő vizsgálata kultúrnövény állományban (RICZU et al., 2015). Így felmerül a kérdés, miként változik a gyomflóra fajösszetétele különbözö tápanyag-ellátottság esetén, továbbá milyen hatással van az összes és fajonkénti gyom egyedszám és biomassza produkció alakulására a növényi fejlődés korai fázisában, kukorica kultúrában?

\section{Vizsgálati anyag és módszer}

A kutatás az MTA ATK Talajtani és Agrokémiai Kutató Intézet nagyhörcsöki (É4651'54”, K18³6’28,8”) kísérleti telepén valósult meg, mészlepedékes csernozjom talajon (FAO Calcaric Phaeosem) 2003-ban beállított trágyázási tartamkísérletben, kukorica állományban (hibrid: Mv 277), amelynek előveteménye kukorica volt. A vetés 2014. április 30-án történt. Öt különböző tápanyagkezelést vizsgáltunk: kontroll (Ø); PK; NK; NP és NPK, három ismétlésben. Az alkalmazott éves mütrágyadózisok az alábbiak voltak: $\mathrm{N}$ : $150 \mathrm{~kg} \mathrm{~N} \cdot \mathrm{ha}^{-1}, \mathrm{P}: 100 \mathrm{~kg} \mathrm{P}_{2} \mathrm{O}_{5} \cdot \mathrm{ha}^{-1}, \mathrm{~K}$ : $100 \mathrm{~kg} \mathrm{~K}_{2} \mathrm{O} \cdot \mathrm{ha}^{-1}$. A foszfor és kálium mütrágyák az öszi szántás előtt, a nitrogén pedig tavasszal került kijuttatásra.

A kísérleti terület felső $20 \mathrm{~cm}$-es rétegéből kezelésenként átlagmintát vettük 2013 őszén, majd vizsgáltuk a főbb talajkémiai tulajdonságait, amelynek eredményeit később ismertetjük (1. táblázat). A terület talajfizikai és -hidrológiai viszonyait LEHOCZKY és munkatársai $(2014,2016)$ mutatják be részleteiben.

A random elhelyezkedésủ parcellák mérete $73,5 \mathrm{~m}^{2}$ volt, melyekben $4,9 \times 5 \mathrm{~m}$ herbicides kezelésben és mechanikai gyomszabályozásban sem részesülő mintaterületek voltak kijelölve. Jelen tanulmány fókuszában a nem gyomirtott területegységek állnak, ahol a gyomfelvételezés, ill. a kukorica és gyomnövény mintavételek 2014. június 3-án és június 18-án, a kukorica 2-4 és 6-8 leveles fejlődési stádiumában (BBCH 2-4 és $\mathrm{BBCH}$ 16-18) történtek. Mütrágya kezelésenként 6 ismétlésben, $1 \mathrm{~m}^{2}$-es területeken végeztük a mintavételezést 
mindkét időpontban. Meghatároztuk a gyomflóra fajösszetételét, a gyomnövények egyedsürüségét, amelyek alapján a gyomnövények egymáshoz viszonyított dominanciáját a Berger-Parker indexszel (MAGURRAN, 1988) számítottuk ki. Továbbá mértük a gyomok földfeletti friss-, és száraz biomassza tömegét, kétlépcsős eljárást alkalmazva: először a mintákat jól szellőző fedett térben fonnyasztottuk, majd szárítószekrényben $40{ }^{\circ} \mathrm{C}$-on tömegállandóságig szárítottuk.

A nagyhörcsöki kísérleti terület éghajlati viszonyait tekintve mérsékelten aszályos, a Pálfai-aszályindex (PÁLFAI \& HERCEG, 2012) értéke 6,1 a 1967-2015-ös időszak vonatkozásában. A 2013/2014-es téli félév csapadékösszege (189,1 mm), amely közel azonos volt a sokéves átlaggal $(209,3 \mathrm{~mm})$. A vetés és az első mintavétel között, 34 nap alatt 57,0 mm csapadék volt, mely teljes egészében május hónapban hullott és a két mintavételi időpont között újabb csapadékeseményt nem rögzítettünk (1. ábra). A május-június havi középhőmérséklet átlagosan $1,3{ }^{\circ} \mathrm{C}-\mathrm{kal}$ volt kevesebb a sokéves átlaghoz képest (1. ábra).

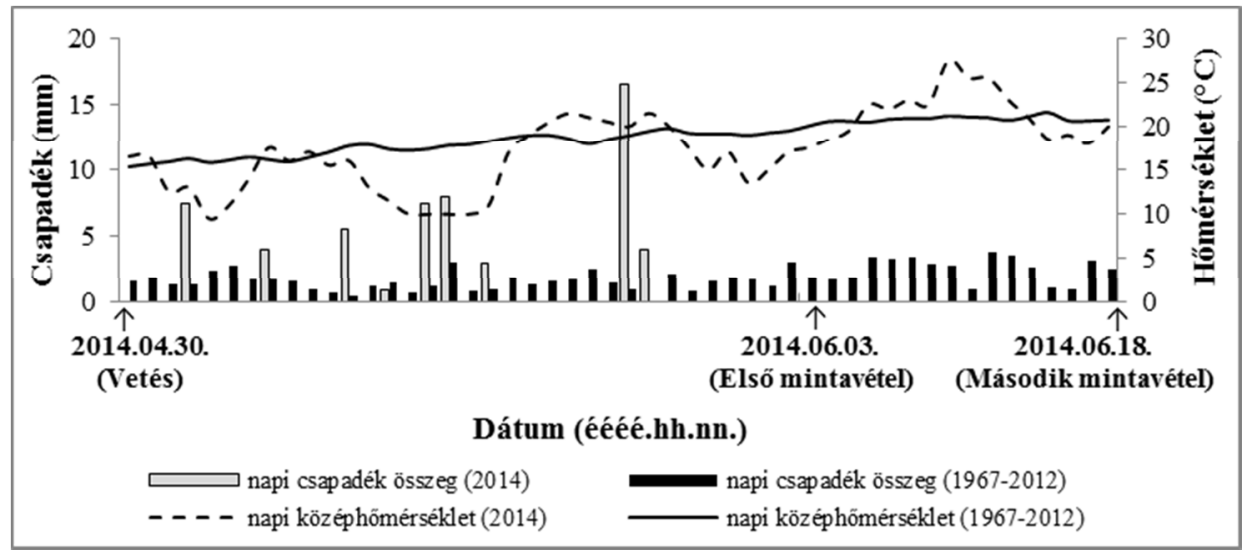

\section{1. ábra}

Napi átlag csapadékösszeg $(\mathrm{mm})$ és napi átlag középhőmérséklet $\left({ }^{\circ} \mathrm{C}\right)$ a vizsgált időszakban április 30 és június 18 között 2014-ben és az 1967-2012 közötti időszak átlagában Nagyhörcsökön

A kísérleti adatok statisztikai elemzéséhez egytényezős varianciaanalízist alkalmaztunk, melyet MSTAT (1988) szoftver segítségével végeztünk el p <0,05 valószínüségi szinten. Az eredmények grafikus ábrázolását Microsoft Excel programmal végeztük.

\section{Vizsgálati eredmények és értékelésük}

\section{Kezelés-specifikus agrokémiai jellemzök}

A nagyhörcsöki kísérleti terület kezelésenkénti fontosabb talajkémiai tulajdonságait az 1. táblázat mutatja be. A talaj AL-oldható foszfortartalma a kontroll és NK kezelésekben átlagosan $106 \mathrm{mg} \cdot \mathrm{kg}^{-1}$-mal volt kevesebb a másik 
három kezelés átlagához képest $\left(183 \mathrm{mg} \cdot \mathrm{kg}^{-1}\right)$. A foszfortartalomhoz hasonlóan a kálium vonatkozásában is a legkisebb értéket a kontroll kezelésben kaptuk, mely valamennyi kezeléshez viszonyítva szignifikánsan kevesebb volt. A legmagasabb AL-oldható káliumtartalmat a PK kezelésben mértük. Ez igazolhatóan több volt a másik két olyan kezeléshez képest, melyek szintén részesültek kálium mütrágyázásban (NK, NPK), lásd. 1. táblázat.

\section{1. táblázat}

A nagyhörcsöki mintaterület jellemző talajkémiai tulajdonságai kezelésenként (Ø, PK, NK, NP és NPK) 2013-ban

\begin{tabular}{|c|c|c|c|c|c|c|}
\hline \multirow{2}{*}{$\begin{array}{c}(1) \\
\text { Kezelés }\end{array}$} & $\mathrm{pH}_{\mathrm{KCl}}$ & $\mathrm{AL}-\mathrm{P}_{2} \mathrm{O}_{5}$ & $\mathrm{AL}-\mathrm{K}_{2} \mathrm{O}$ & $\begin{array}{c}\text { (2) } \\
\text { Humusz }\end{array}$ & (3) Só & $\mathrm{CaCO}_{3}$ \\
\cline { 2 - 7 } & - & \multicolumn{2}{|c|}{$\mathrm{mg} \cdot \mathrm{kg}^{-1}$} & \multicolumn{3}{|c|}{$\%$} \\
\hline$\varnothing$ & 7,25 & 76 & 126 & 3,05 & 0,03 & 4,8 \\
$\mathrm{PK}$ & 7,28 & 187 & 256 & 3,21 & 0,04 & 4,2 \\
$\mathrm{NK}$ & 7,28 & 79 & 215 & 3,20 & 0,04 & 4,7 \\
$\mathrm{NP}$ & 7,22 & 169 & 154 & 3,23 & 0,05 & 3,2 \\
$\mathrm{NPK}$ & 7,22 & 193 & 209 & 3,16 & 0,05 & 3,1 \\
\hline (4) $\mathrm{SzD}_{5 \%}$ & n.s. & 20 & 19 & 0,15 & n.s. & n.s. \\
\hline
\end{tabular}

Megjegyzés: n.s. = nem szignifikáns

Megállapítható, hogy a kontroll terület foszforral és káliummal gyengén ellátott, míg az NPK kezelésben részesülő parcellák talaja foszforban jól, káliumban közepesen-jól ellátott volt (BUZÁs, 1979). A talaj humusztartalma a kontroll kezelésben volt a legkisebb, szignifikánsan kevesebb, mint a PK, NK és NP kezelésekben. (1. táblázat).

Ezen agrokémiai tulajdonságok hatással vannak a gyomdiverzitásra, a gyomok egyedszámára és a biomassza produkciójuk alakulására is, melyet a következő alfejezetekben részletezünk.

\section{Gyomflóra diverzitás jellemzése}

A kukorica 2-4 és 6-8 leveles fejlettségénél végzett mintavételek időpontjában összesen 22 gyomfaj fordult elö a kísérletben 2014-ben (2. táblázat). Az első mintavételi időpontban összesen 18, a másodikban 19 fajt írtunk le, amelyek közül hét gyomnövényfaj előfordulása szórványos volt. A felvételezett gyomnövény fajok 14 növénycsaládba tartoznak, amelyek közül a Poaceae család volt a legnépesebb négy fajjal.

Életformájukat tekintve a fajok döntő többsége, $82 \%$-a a $\mathrm{T}_{4}$-es típusba tartozó melegigényes egyéves gyomnövény volt. Ezen kívül évelö fajok is elöfordultak: egy rizómás $\left(\mathrm{G}_{1}\right)$, két szaporítógyökeres $\left(\mathrm{G}_{3}\right)$ valamint egy szaporodásra nem képes karógyökerü $\left(\mathrm{H}_{4}\right)$ faj. 
2. táblázat

A gyomnövény fajok előfordulási gyakoriság szerinti listája Nagyhörcsökön a kukorica korai fenológiai fázisában (BBCH12-14 és BBCH16-18) 2014. június 3 és 18-án.

\begin{tabular}{|c|c|c|c|c|c|c|}
\hline \multirow{2}{*}{\multicolumn{2}{|c|}{$\begin{array}{c}\text { (1) } \\
\text { Gyomnövény faj }\end{array}$}} & \multirow{3}{*}{$\begin{array}{c}(2) \\
\text { EPPO kód } \\
\text { AMBEL }\end{array}$} & \multirow{3}{*}{$\begin{array}{c}\begin{array}{c}(3) \\
\text { Élet- } \\
\text { forma }\end{array} \\
\mathrm{T}_{4}\end{array}$} & \multicolumn{3}{|c|}{ (4) Gyakoriság } \\
\hline & & & & \multirow{2}{*}{$\frac{06.03 .}{30}$} & \multirow{2}{*}{$\begin{array}{c}06.18 . \\
30\end{array}$} & \multirow{2}{*}{$\begin{array}{l}(5) \\
\text { Átlag } \\
30,0\end{array}$} \\
\hline 1. & Ambrosia artemisiifolia $\mathrm{L}$. & & & & & \\
\hline 2. & Datura stramonium $\mathrm{L}$. & DATST & $\mathrm{T}_{4}$ & 29 & 27 & 28,0 \\
\hline 3. & Sorghum halepense (L.) Pers. & SORHA & $\mathrm{G}_{1}$ & 19 & 27 & 23,0 \\
\hline 4. & Fallopia convolvulus (L.) A. Löve & POLCO & $\mathrm{T}_{4}$ & 22 & 22 & 22,0 \\
\hline 5 . & Solanum nigrum $\mathrm{L}$. & SOLNI & $\mathrm{T}_{4}$ & 14 & 29 & 21,5 \\
\hline 6. & Chenopodium album $\mathrm{L}$. & CHEAL & $\mathrm{T}_{4}$ & 21 & 17 & 19,0 \\
\hline 7. & Chenopodium hybridum L. & CHEHY & $\mathrm{T}_{4}$ & 19 & 18 & 18,5 \\
\hline 8 . & Helianthus annuus L. & HELAN & $\mathrm{T}_{4}$ & 14 & 11 & 12,5 \\
\hline 9. & Heliotropium europaeum L. & HEOEU & $\mathrm{T}_{4}$ & 13 & 9 & 11,0 \\
\hline 10. & Hibiscus trionum $\mathrm{L}$. & HIBTR & $\mathrm{T}_{4}$ & 4 & 14 & 9,0 \\
\hline 12. & Amaranthus blitoides $\mathrm{S}$. Watson & AMABL & $\mathrm{T}_{4}$ & 7 & 9 & 8,0 \\
\hline 11. & Convolvulus arvensis $\mathrm{L}$. & CONAR & $\mathrm{G}_{3}$ & 10 & 6 & 8,0 \\
\hline 13. & Stachys aппиа $\mathrm{L}$. & STAAN & $\mathrm{T}_{4}$ & 6 & 9 & 7,5 \\
\hline 14. & Setaria pumila (Poir.) Schult. & SETPU & $\mathrm{T}_{4}$ & 7 & 6 & 6,5 \\
\hline 15. & Amaranthus hybridus L. & AMACH & $\mathrm{T}_{4}$ & 7 & 1 & 4,0 \\
\hline 16. & Ajuga chamaepitys (L.) Schreb. & AIUCH & $\mathrm{T}_{4}$ & 1 & 0 & 0,5 \\
\hline 19. & Cardaria draba (L.) Desv. & CADDR & $\mathrm{G}_{3}$ & 0 & 1 & 0,5 \\
\hline 20. & Chaenorrhinum minus (L.) Lange & CHNMI & $\mathrm{T}_{4}$ & 0 & 1 & 0,5 \\
\hline 17. & Panicum miliaceum L. & PANMI & $\mathrm{T}_{4}$ & 1 & 0 & 0,5 \\
\hline 21. & Portulaca oleracea L. & POROL & $\mathrm{T}_{4}$ & 0 & 1 & 0,5 \\
\hline 18. & Reseda lutea L. & RESLU & $\mathrm{H}_{4}$ & 1 & 0 & 0,5 \\
\hline 22. & Setaria viridis (L.) P. B. & SETVI & $\mathrm{T}_{4}$ & 0 & 1 & 0,5 \\
\hline
\end{tabular}

Megjegyzés: A fajok életformáját UJVÁROSI (1973) nyomán adtuk meg.

Az ürömlevelü parlagfü (Ambrosia artemisiifolia L.) minden kezelés minden parcellájában megjelent, ugyanakkor a csattanó maszlag (Datura stramonium L.), a fenyércirok (Sorghum halepense (L.) Pers.), a szulák keserüfü (Fallopia convolvulus (L.) A. Löve.), a fekete csucsor (Solanum nigrum L.), a fehér libatop (Chenopodium album L.) és pokolvar libatop (Chenopodium hybridum L.) előfordulási gyakorisága is magas volt. Az A. artemisiifolia nagymértékü elterjedéséhez hozzájárul, hogy magas az abiotikus stressz iránti tủrőképessége, ezért mind alacsony, mind pedig magas tápanyagellátottságú talajokon megjelenik (LEHOCZKY, 2004b). Vízigénye is széles skálán változik, aszályra érzékenyebb területeken is elöfordul, de az $592 \mathrm{~mm}$-t meghaladó éves csapadékmennyiség nagyobb egyedszám kialakulását eredményezheti (PINKE et al., 2011).

A S. nigrum és a varjúmák (Hibiscus trionum L.) előfordulása jelentősen nagyobb volt a második mintavételi időpontban, mivel mindkét faj $\mathrm{T}_{4}$-es életformájú, azon belül is kifejezetten melegigényes, így tömeges kelésük $20^{\circ} \mathrm{C}$ fölött következett be. 
Gyom egyedszám és dominanciaviszonyok

A gyomflóra diverzitás, ill. dominancia viszonyok részletes vizsgálatát is elvégeztük. A 2. ábra szemlélteti a $0,1 \mathrm{db} \cdot \mathrm{m}^{-2}-\mathrm{t}$ meghaladó egyedsürüségü gyomnövényfajok számát a kezelések és mintavételi időpontok átlagában $(n=12)$.

A kontroll, PK és NK kezelésekben az A. artemisiifolia átlagosan az összes gyomegyedszám 70,7\%-át $\left(76,5 \mathrm{db} \cdot \mathrm{m}^{-2}\right)$ alkotta (2. ábra), míg az NP és NPK kezelésekben az egyedsürüsége szignifikánsan kevesebb volt $\left(25,4\right.$ és $7,0 \mathrm{db} \cdot \mathrm{m}^{-2}$; $\left.\mathrm{SzD}_{5 \%}=20,0 \mathrm{db} \cdot \mathrm{m}^{-2}\right)$. A kontrollban fö vetélytársa a $S$. halepense $\left(26,3 \mathrm{db} \cdot \mathrm{m}^{-2}\right)$ volt, amely ebben a kezelésben igazolhatóan $\left(\mathrm{SzD}_{5 \%}=8,4 \mathrm{db} \cdot \mathrm{m}^{-2}\right)$ nagyobb egyedszámmal volt jelen a többi kezeléshez képest. A PK és NK kezelésekben a $D$. stramonium $\left(6,9 \mathrm{db} \cdot \mathrm{m}^{-2}\right.$ és $\left.6,2 \mathrm{db} \cdot \mathrm{m}^{-2}\right)$ és a $S$. halepense $\left(5,6 \mathrm{db} \cdot \mathrm{m}^{-2}\right.$ és $\left.6,2 \mathrm{db} \cdot \mathrm{m}^{-2}\right)$ voltak jelen jelentősebb egyedszámmal (2. ábra).

A NPK kezelésben az A. artemisiifolia visszaszorult $\left(7,0 \mathrm{db} \cdot \mathrm{m}^{-2}\right)$ és a két libatop faj (C. album és $C$. hybridum) vált dominánssá, egyedszámuk együttesen $85,2 \mathrm{db} \cdot \mathrm{m}^{-}$ 2 volt $\left(\mathrm{SzD}_{5 \%} \mathrm{CHEAL}=22,9 \mathrm{db} \cdot \mathrm{m}^{-2} ; \mathrm{SzD}_{5 \%} \mathrm{CHEHY}=3,4 \mathrm{db} \cdot \mathrm{m}^{-2}\right)$. Fö vetélytársuk $20,6 \%$-os aránnyal a $D$. stramonium volt $\left(\mathrm{SzD}_{5 \%}=5,5 \mathrm{db} \cdot \mathrm{m}^{-2}\right)(2$ ábra $)$. Ezek a fajok nitrogénkedvelők és a jó foszforellátottság is kedvező számukra (LEHOCZKY, 2003).

A fajösszetételt és dominancia viszonyokat tekintve az NP kezelés volt a legkiegyenlítettebb, az előforduló 14 faj közül egyik sem tudott 50\%-ot meghaladó részarány fölé emelkedni. A meghatározó fajok az alábbiak voltak: A. artemisiifolia $\left(25,4 \mathrm{db} \cdot \mathrm{m}^{-2}\right)$, C. album $\left(19,0 \mathrm{db} \cdot \mathrm{m}^{-2}\right)$, C. hybridum $\left(13,7 \mathrm{db} \cdot \mathrm{m}^{-2}\right)$ és D. stramonium $\left(9,4 \mathrm{db} \cdot \mathrm{m}^{-2}\right)(2 . a ́ b r a)$.

A kisebb egyedszámmal jelen lévő fajok közül az árvakelésű napraforgónak (Helianthus annuus L.) a kontroll és PK, a S. nigrum számára az NP, a fakó muhar [Setaria pumila (Poir.) Schult.] számára a PK kezelés biztosította az optimálisabb feltételeket, így ezekben a kezelésekben egyedszámuk igazolhatóan nagyobb volt a többihez képest $\left(\mathrm{SzD}_{5 \%} \mathrm{HELAN}=0,7 \mathrm{db} \cdot \mathrm{m}^{-2} ; \quad \mathrm{SzD}_{5 \%} \mathrm{SOLNI}=1,3 \mathrm{db} \cdot \mathrm{m}^{-2}\right.$; $\mathrm{SzD}_{5 \%} \mathrm{SETPU}=3,7 \mathrm{db} \cdot \mathrm{m}^{-2}$; ). A F. convolvulus a foszforral ellátott PK, NP és NPK, a henye disznóparéj (Amaranthus blitoides S. Watson) és karcsú disznóparéj (Amaranthus hybridus L.) az NPK kezelésben volt szignifikánsan nagyobb egyedszámmal jelen $\left(\mathrm{SzD}_{5 \%} \mathrm{POLCO}=1,3 \mathrm{db} \cdot \mathrm{m}^{-2} ; \mathrm{SzD}_{5 \%} \mathrm{AMABL}=1,4 \mathrm{db} \cdot \mathrm{m}^{-2}\right.$; $\mathrm{SzD}_{5 \%} \mathrm{AMACH}=2,2 \mathrm{db} \cdot \mathrm{m}^{-2}$ ). A $H$. trionum és a tarlóvirág (Stachys annua L.) a kontroll kezelést részesítették előnyben $\left(\mathrm{SzD}_{5 \%} \mathrm{HIBTR}=0,8 \mathrm{db} \cdot \mathrm{m}^{-2}\right.$; $\left.\mathrm{SzD}_{5 \%} \mathrm{STAAN}=0,7 \mathrm{db} \cdot \mathrm{m}^{-2}\right)(2$. ábra $)$.

Mindkét mintavételi időpontban hasonló egyedszámokat tapasztaltunk az egyes fajok esetében, azonban négy növényfaj egyedszáma szignifikáns eltérést mutatott a két időpont között. A C. hybridum esetében közel 80\%-os növekedést tapasztaltunk, mely az NP kezelés esetében (2014.06.03.: 10,1 db·m $\mathrm{m}^{-2}$ 2014.06.18.: 17,3 db·m $\mathrm{m}^{-2}$ ) statisztikailag is igazolható volt $\left(\mathrm{SzD}_{5 \%}=5,5 \mathrm{db} \cdot \mathrm{m}^{-2}\right)$. A tápanyagban gazdag talajokat előnyben részesítő (WEAVER \& WARWICK, 1984) D. stramonium egyedszáma a PK (2014.06.03.: 11,1 $\mathrm{db} \cdot \mathrm{m}^{-2} ; 2014.06 .18 .: 2,7 \mathrm{db} \cdot \mathrm{m}^{-2}$ ) és NK (2014.06.03.: 9,1 $\mathrm{db} \cdot \mathrm{m}^{-2}$; 2014.06.18.: 3,4 $\mathrm{db} \cdot \mathrm{m}^{-2}$ ) kezelésekben szignifikáns 
csökkenést mutatott $\left(\mathrm{SzD}_{5 \%} \mathrm{PK}=7,2 \mathrm{db} \cdot \mathrm{m}^{-2} ; \mathrm{SzD}_{5 \%} \mathrm{NK}=3,7 \mathrm{db} \cdot \mathrm{m}^{-2}\right)$ az első mintavételi időponthoz képest.

A S. halepense egyedszáma a kezelések átlagában több mint 140\%-kal volt magasabb a 2. mintavételi időpontban. A növekedés a kontroll (2014.06.03.: 14,4 $\mathrm{db} \cdot \mathrm{m}^{-2}$; 2014.06.18.: 38,2 $\left.\mathrm{db} \cdot \mathrm{m}^{-2}\right)$ és NK (2014.06.03.: 3,6 db $\cdot \mathrm{m}^{-2} ; 2014.06 .18 .: 8,9$ $\left.\mathrm{db} \cdot \mathrm{m}^{-2}\right)$ kezelésekben szignifikáns volt $\left(\mathrm{SzD}_{5 \%} \varnothing=22,7 \mathrm{db} \cdot \mathrm{m}^{-2} ; \mathrm{SzD}_{5 \%} \mathrm{NK}=3,2\right.$ $\mathrm{db} \cdot \mathrm{m}^{-2}$ ). A $S$. halepense egyedszámában bekövetkező nagyarányú változás feltehetöen a kétféle szaporodási stratégiájának köszönhető, mind vegetatív (rizóma) mind generatív (mag) úton képes szaporodni. Szántóföldi körülmények között általában a rizómáról történő kihajtás megelőzi a magvak csírázását (DOBSZAI-TÓTH ÉS LEHOCZKY, 2010; NovÁK el al., 2011).

A S. nigrum egyedszáma az NK kezelésben a két mintavételi időpont között szintén szignifikánsan növekedett $0,2 \mathrm{db} \cdot \mathrm{m}^{-2}-$ röl $2,3 \mathrm{db} \cdot \mathrm{m}^{-2}-\mathrm{re}\left(\mathrm{SzD}_{5 \%}=1,7 \mathrm{db} \cdot \mathrm{m}^{-2}\right)$. A C. album egyedszáma két hét alatt átlagosan $27 \%$-kal nőtt, azonban heterogén előfordulása miatt ez a növekedés nem volt szignifikáns.

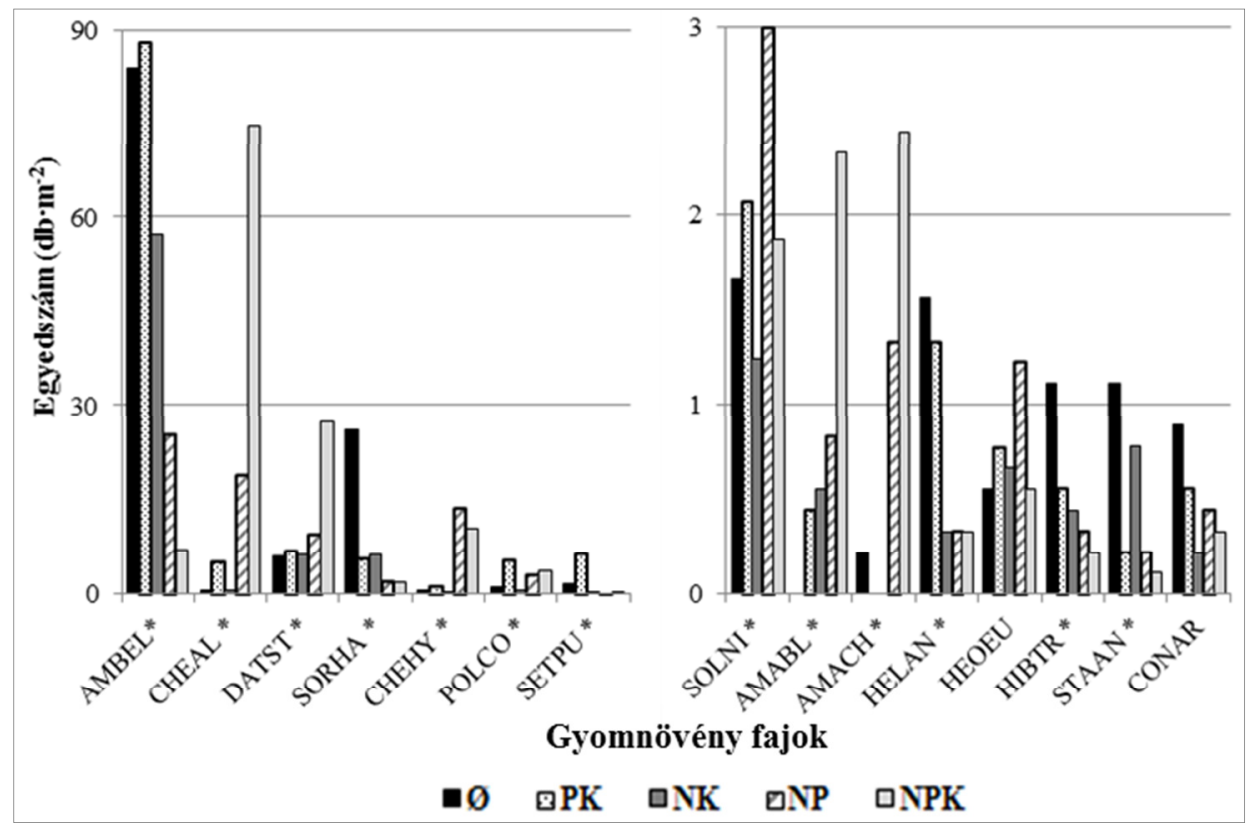

2. ábra

A gyomnövény fajok egyedsürüsége $\left(\mathrm{db} \cdot \mathrm{m}^{-2}\right)$ a vizsgált tápanyagkezelésekben $(\varnothing, \mathrm{PK}, \mathrm{NK}$, NP és NPK) a két mintavétel (2014. 06. 03. és 2014. 06.18.) átlagában Nagyhörcsökön $(\mathrm{n}=12)$. Gyomnövény fajok listája: 2 . táblázat.

Megjegyzés: * a szignifikáns különbségeket jelöli $(\mathrm{p}<0,05)$

A 3. táblázatban a két mintavételi időpont átlagában szerepeltettük annak a kilenc gyomnövény fajnak a dominancia sorrendjét, amelyek az összes egyedszám több mint 95\%-át alkották. Az értékek változásai jól mutatják az eltérő tápanyag- 
ellátottság következtében kialakuló interspecifikus kompetíció hatását. A kísérletben az A. artemisiifolia volt a domináns faj, a kezelések átlagában az összes gyomnövény csaknem felét alkotta. Legjelentősebb két versenytársa a $C$. album és a D. stramonium volt, amelyek a kiegyensúlyozott ellátottságot biztosító NPK kezelésben voltak képesek visszaszorítani a parlagfüvet (3. táblázat). LESKOVŠEK és munkatársai (2012) kutatásuk során megállapították, hogy az A. artemisiifolia kiváló alkalmazkodóképességgel rendelkezik, azonban gazdag tápanyag- és vízellátottságú környezetben kompetíciós képessége gyengébb, melyet eredményeink is igazoltak (lásd 2. ábra és 3. táblázat).

A $S$. halepense a kontroll kezelésben a második volt a dominancia sorrendben, míg az összesített sorrendben a negyedik. A C. hybridum a nitrogénnel és foszforral egyaránt ellátott kezeléseket részesítette előnyben, mind az NP, mind az NPK kezelésekben harmadik volt a dominancia sorrendben. A $F$. convolvulus a foszforral ellátott kezeléseket preferálta, de ezekben sem ért el jelentős részesedést. Ez nem meglepő, mivel a versenyképességét alapvetően meghatározza a kultúrnövény faja, elsődlegesen gabonagyomként tartják számon (NOVÁK el al., 2011) (3. táblázat).

\section{3. táblázat}

Gyomnövény fajok dominancia sorrendje a vizsgált tápanyagkezelésekben (Ø, PK, NK, NP és NPK) Nagyhörcsökön a két mintavételi időpont (2014. 06. 03. és 2014. 06.18.) dominancia indexei alapján

\begin{tabular}{|l|c|c|c|c|c|c|}
\hline \multicolumn{1}{|c|}{$\begin{array}{c}(1) \\
\text { Gyomnövény faj }\end{array}$} & $\varnothing$ & PK & NK & NP & NPK & $\begin{array}{c}(2) \\
\text { Átlag }\end{array}$ \\
\hline Ambrosia artemisiifolia L. & $\underline{0,666}$ & $\underline{0,689}$ & $\underline{0,740}$ & $\underline{0,338}$ & 0,060 & 0,495 \\
Chenopodium album L. & 0,005 & 0,043 & 0,009 & $\underline{0,199}$ & $\underline{0,505}$ & 0,160 \\
Datura stramonium L. & 0,048 & $\underline{0,064}$ & $\underline{0,088}$ & $\underline{0,123}$ & $\underline{0,234}$ & 0,114 \\
Sorghum halepense (L.) Pers. & $\underline{0,192}$ & 0,047 & 0,083 & 0,026 & 0,013 & 0,068 \\
Chenopodium hybridum L. & 0,005 & 0,010 & 0,006 & 0,172 & 0,085 & 0,055 \\
Fallopia convolvulus (L.) Á. Löve & 0,011 & 0,047 & 0,008 & 0,038 & 0,028 & 0,027 \\
Solanum nigrum L. & 0,013 & 0,020 & 0,018 & 0,038 & 0,015 & 0,022 \\
Setaria pumila (Poir.) Schult. & 0,011 & 0,047 & 0,005 & 0,001 & 0,005 & 0,012 \\
Amaranthus hybridus L. & 0,003 & 0,000 & 0,000 & 0,017 & 0,023 & 0,008 \\
Egyéb fajok (3) & 0,046 & 0,034 & 0,044 & 0,047 & 0,034 & 0,039 \\
\hline (4) Összesen & 1,000 & 1,000 & 1,000 & 1,000 & 1,000 & 1,000 \\
\hline
\end{tabular}

Gyom biomassza produkció változások

A gyomdominancia elemzése mellett elvégeztük a gyom biomassza produkció részletes vizsgálatát minden elöforduló növényfajra.

$\mathrm{Az}$ első mintavételi időpontban (2016.06.03.) a kontroll, PK és NK kezelésekben a száraz tömegek alapján az A. artemisiifolia volt az uralkodó faj, az összes gyomtömegen belüli aránya 73,2\% (Ø); 60,4\% (PK) ill. 86,4\% (NK) volt (4. táblázat). A PK kezelés kedvezett a $F$. convolvulus és a $H$. anuus biomassza produkciójának, az összes száraz gyomtömeg 13-13\%-át alkották. 
Az NPK kezelésben a Chenopodium spp. és a D. stramonium alkották az összes száraz gyomtömeg több mint $70 \%$-át. Az NP kezelés nem csak az egyedszám tekintetében volt kiegyenlített. A száraz tömeg vonatkozásában a korábban említett négy fajon kívül meg kell említenünk az árvakelésủ napraforgót, mely az össztömeg több mint negyedét $\left(1,56 \mathrm{~g} \cdot \mathrm{m}^{-2}\right)$ tette ki.

A kísérletben elöforduló füfélék közül a $S$. halepense a kontroll, a $S$. pumila a PK kezelésben képeztek szignifikánsan több biomasszát a többi kezeléshez viszonyítva (4. táblázat).

\section{4. táblázat}

A gyomfajok száraz biomassza tömege $\left(\mathrm{g} \cdot \mathrm{m}^{-2}\right)$ a különbözö tápanyagkezelésekben (Ø, PK, NK, NP és NPK) és azok átlagában Nagyhörcsökön 2014.06.03-án.

\begin{tabular}{|c|c|c|c|c|c|c|c|}
\hline \multirow{2}{*}{$\begin{array}{c}(1) \\
\text { Gyomnövény faj }\end{array}$} & \multicolumn{6}{|c|}{ (2) Száraz biomassza tömeg $\left(\mathrm{g} \cdot \mathrm{m}^{-2}\right)$} & \multirow{2}{*}{\begin{tabular}{|c|}
$(3)$ \\
$\mathrm{SzD}_{5 \%}$
\end{tabular}} \\
\hline & $\varnothing$ & PK & NK & NP & NPK & Átlag & \\
\hline Ambrosia artemisiifolia $\mathrm{L}$. & 4,91 & 12,55 & 4,24 & 1,62 & 0,49 & 4,76 & 4,46 \\
\hline Chenopodium album $\mathrm{L}$. & 0,02 & 0,62 & 0,02 & 0,60 & 7,41 & 1,73 & 3,43 \\
\hline Helianthus annuus L. & 0,76 & 2,72 & 0,18 & 1,56 & 0,84 & 1,21 & 2,25 \\
\hline Fallopia convolvulus (L.) A. Löve & 0,02 & 2,76 & 0,004 & 0,52 & 1,80 & 1,02 & 1,71 \\
\hline Datura stramonium $\mathrm{L}$. & 0,14 & 1,36 & 0,27 & 0,61 & 2,34 & 0,94 & 0,88 \\
\hline Chenopodium hybridum L. & 0,01 & 0,10 & 0,01 & 0,63 & 0,26 & 0,20 & 0,48 \\
\hline Sorghum halepense (L.) Pers. & 0,50 & 0,19 & 0,09 & 0,02 & 0,02 & 0,16 & 0,34 \\
\hline Convolvulus arvensis $\mathrm{L}$. & 0,26 & 0,04 & 0,03 & 0,03 & 0,03 & 0,08 & n.s. \\
\hline Amaranthus hybridus L. & 0,01 & & & 0,09 & 0,17 & 0,06 & 0,16 \\
\hline Setaria pumila (Poir.) Schult. & 0,02 & 0,18 & 0,01 & 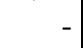 & 0,03 & 0,05 & 0,15 \\
\hline Amaranthus blitoides $\mathrm{S}$. Watson & - & 0,09 & 0,02 & 0,03 & 0,10 & 0,05 & n.s. \\
\hline Solanum nigrum L. & 0,01 & 0,09 & 0,00 & 0,06 & 0,02 & 0,04 & n.s. \\
\hline Hibiscus trionum $\mathrm{L}$. & 0,03 & 0,04 & & 0,05 & - & 0,02 & n.s. \\
\hline Heliotropium europaeum $\mathrm{L}$. & 0,01 & 0,02 & 0,01 & 0,02 & 0,02 & 0,02 & n.s. \\
\hline Stachys annua L. & 0,01 & 0,00 & 0,01 & - & 0,01 & 0,01 & n.s. \\
\hline Reseda lutea $\mathrm{L}$. & - & 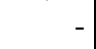 & 0,02 & - & - & 0,00 & n.s. \\
\hline Panicum miliaceum $\mathrm{L}$. & - & - & 0,00 & - & - & 0,00 & n.s. \\
\hline Ajuga chamaepitys (L.) Schreb. & 0,00 & - & - & - & - & 0,00 & n.s. \\
\hline
\end{tabular}

Megjegyzés: n.s. = nem szignifikáns

A második mintavétel idején, 15 nappal később a kontroll, PK és NK kezelésekben továbbra is az A. artemisiifolia volt az uralkodó faj, az összes gyomtömegen belüli aránya 60,3\% (Ø), 60,4\% (PK) ill. 78,3\% (NK) volt (5. táblázat). A $S$. halepense aránya a kontroll $(24,6 \%)$ és NK (10,7\%) kezelésekben volt jelentős.

A $F$. convolvulus a PK kezelésben az összes száraz gyomtömeg közel ötödét tette ki (5. táblázat). A nitrogént és foszfort kedvelő Chenopodium spp. és a $D$. stramonium alkották az összes száraz gyomtömeg 70,7\% és 88,6\%-át az NP és NPK kezelésekben.

Egyes fajoknak az egyedszámnál kapott arányoktól eltérő volt a gyomflórán belüli száraz tömeg szerinti aránya. A különbözőséget a fajok eltérő morfológiai 
tulajdonságai és növekedési jellemzői eredményezték, így pl. a $H$. annuиs részesedése az összes egyedszámból átlagosan $0,5 \%$, míg az összes száraz tömeg esetében egy nagyságrenddel nagyobb $(5,5 \%)$ volt. A $F$. convolvulus száraz tömeg szerinti $(18,2 \%)$ aránya négyszer nagyobb volt a PK kezelésben, mint az egyedszám szerint $(4,9 \%)$.

\section{5. táblázat}

A gyomfajok száraz biomassza tömege $\left(\mathrm{g} \cdot \mathrm{m}^{-2}\right)$ a különböző tápanyagkezelésekben $(\varnothing, \mathrm{PK}$, NK, NP és NPK) és azok átlagában Nagyhörcsökön 2014.06.18-án.

\begin{tabular}{|c|c|c|c|c|c|c|c|}
\hline \multirow{2}{*}{$\begin{array}{c}\text { (1) } \\
\text { Gyomnövény faj }\end{array}$} & \multicolumn{6}{|c|}{ (2) Száraz biomassza tömeg $\left(\mathrm{g} \cdot \mathrm{m}^{-2}\right)$} & \multirow{2}{*}{$\begin{array}{c}(3) \\
\mathrm{SzD}_{5 \%} \\
\end{array}$} \\
\hline & $\varnothing$ & PK & NK & NP & NPK & Átlag & \\
\hline Ambrosia artemisiifolia L. & 29,98 & 75,47 & 31,58 & 18,23 & 6,00 & 32,25 & 15,36 \\
\hline Chenopodium album $\mathrm{L}$. & 0,04 & 3,50 & - & 33,66 & 72,81 & 22,00 & 32,89 \\
\hline Datura stramonium L. & 1,72 & 1,94 & 1,29 & 17,34 & 15,21 & 7,50 & 6,63 \\
\hline Chenopodium hybridum L. & 0,10 & 0,99 & 0,02 & 10,18 & 18,09 & 5,88 & 5,94 \\
\hline Fallopia convolvulus (L.) A. Löve & 0,13 & 22,80 & 0,02 & 2,85 & 2,89 & 5,74 & 12,99 \\
\hline Helianthus annuus L. & 4,06 & 15,64 & 1,87 & - & 2,80 & 4,87 & 9,21 \\
\hline Sorghum halepense (L.) Pers. & 12,20 & 1,22 & 4,32 & 1,01 & 0,50 & 3,85 & 4,41 \\
\hline Solanum nigrum $\mathrm{L}$. & 0,13 & 1,03 & 0,16 & 1,14 & 0,33 & 0,56 & 0,70 \\
\hline Amaranthus blitoides S. Watson & & 0,15 & & 0,81 & 1,05 & 0,40 & 0,94 \\
\hline Convolvulus arvensis $\mathrm{L}$. & 0,11 & 1,02 & 0,40 & 0,04 & & 0,32 & n.s. \\
\hline Setaria pumila (Poir.) Schult. & 0,35 & 0,99 & 0,15 & 0,03 & 0,04 & 0,31 & 0,77 \\
\hline Hibiscus trionum $\mathrm{L}$. & 0,75 & 0,08 & 0,20 & 0,09 & 0,07 & 0,24 & 0,63 \\
\hline Heliotropium europaeum $\mathrm{L}$. & - & 0,02 & 0,18 & 0,63 & 0,03 & 0,17 & 0,54 \\
\hline Amaranthus hybridus L. & - & & & 0,40 & & 0,08 & n.s. \\
\hline Stachys annua $\mathrm{L}$. & 0,11 & 0,05 & 0,04 & 0,02 & & 0,05 & 0,10 \\
\hline Chaenorrhinum minus (L.) L & - & 0,13 & & - & - & 0,03 & n.s. \\
\hline Setaria viridis (L.) P. B. & - & 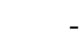 & 0,10 & & - & 0,02 & n.s. \\
\hline Portulaca oleracea L. & - & 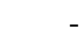 & & 0,09 & & 0,02 & n.s. \\
\hline Cardaria draba (L.) Desv. & - & - & & & 0,01 & 0,00 & n.s. \\
\hline
\end{tabular}

Megjegyzés: n.s. = nem szignifikáns

A kezelések átlagát tekintve a kiemelt fajok tömegének részaránya két hét alatt az alábbiak szerint változott: az A. artemisiifolia és a $D$. stramonium aránya nem változott jelentösen, a $H$. annuиs aránya 50\%-kal csökkent, míg a Chenopodium fajoké átlagosan közel 60\%-kal nött. A S. halepense az egyedszámhoz hasonlóan a száraz tömeg esetében is jelentős növekedést produkált a kontroll és NK kezelésekben, melynek oka szaporodásbiológiai tulajdonságaiból adódhat. TóTH \& LEHOCZKY (2006) kutatásuk során azt tapasztalták, hogy a magról kelő egyedek kezdeti fejlődése lassú, a biomassza produkció üteme június második felétől növekszik jelentősen. Ezen felül közrejátszhatott még az a tényező is, hogy a két mintavétel között nem hullott csapadék, amely kedvezhetett a $\mathrm{C}_{4}$-es fotoszintézisü S. halepense szárazanyag képzésének (LEHOCZKY \& TóTH, 2005). 
A kezelések hatásának értékelése az összes gyom egyedsürüség és száraz biomassza tömegek vonatkozásában

A gyomok összes egyedszámát és együttes föld feletti száraz biomassza tömegét a két mintavételi időpontban, tápanyag-kezelésenként a 6. táblázat mutatja be. Az egytényezős varianciaanalízis $(\mathrm{p}<0,05)$ szignifikáns különbségeket mutatott a különböző tápanyagkezelések hatására mind az egyedsürüség, mind a száraz biomasszatömegek esetében.

A kukorica 2-4 leveles fejlettségi állapotának időpontjában az NK és NP kezelésben volt a legkisebb a gyomnövények egyedsürüsége (71,6 és 74,3 db· $\left.{ }^{-2}\right)$, míg a másik három kezelésben (kontroll, PK, NPK), ennek több mint másfélszeresét mértük (117,3-126,7 db· $\left.\mathrm{m}^{-2}\right)$. A következő 15 nap alatt az összes gyomegyedsürüség 14\%-kal emelkedett, amely alapvetően a C. album, C. hybridum és $S$. halepense egyedszám-növekedésének eredménye. A legkisebb egyedsürüség továbbra is az NK kezelésben $\left(80,4 \mathrm{db} \cdot \mathrm{m}^{-2}\right)$, a legnagyobb pedig az NPK-ban $(141,6$ $\mathrm{db} \cdot \mathrm{m}^{-2}$ ) volt, így a kezelések sorrendje a gyomegyedszám vonatkozásában mindkét vizsgálati időpontban a következőképpen alakult: $\mathrm{NK}<\mathrm{NP}<\mathrm{PK}<\emptyset<\mathrm{NPK}$. Ezen eredményünket a mintaterületen folytatott korábbi kutatás (LEHOCZKY et al., 2014) is alátámasztja. YIN és munkatársai (2006) szintén kukorica kultúrában, trágyázási tartamkísérletben vizsgálták a gyomflóra összetételét, ahol a gyom egyedsürüség 35,2-163,3 db·m ${ }^{-2}$ között változott és az alábbiak szerint alakult: $\mathrm{NP}<\mathrm{NPK}<\mathrm{NK}<\mathrm{PK}<\varnothing$. Ezzel szemben KHAN és munkatársai (2013) kísérletében a kezelések sorrendje - 111,0-145,7 db·m ${ }^{-2}$ közötti gyom egyedsürüség mellett - a következő volt: $\mathrm{PK}<\mathrm{NK}<\mathrm{NP}<\varnothing<\mathrm{NPK}$.

$$
\text { 6. táblázat }
$$

Összesített gyom egyedsürüség $\left(\mathrm{db} \cdot \mathrm{m}^{-2}\right)$ és száraz biomassza tömeg $\left(\mathrm{g} \cdot \mathrm{m}^{-2}\right)$ kezelésenként (Ø, PK, NK, NP és NPK) a két mintavételi időpontban (2014.06.03 és 2014.06.18) Nagyhörcsökön

\begin{tabular}{|c|c|c|c|c|}
\hline \multirow{2}{*}{$\begin{array}{c}(1) \\
\text { Kezelés }\end{array}$} & \multicolumn{2}{|c|}{$\begin{array}{c}\text { (2) Összes gyom egyedsürüség } \\
\left(\mathrm{db} \cdot \mathrm{m}^{-2}\right)\end{array}$} & \multicolumn{2}{c|}{$\begin{array}{c}\text { (3) Összes gyom száraz biomassza } \\
\text { tömeg }\left(\mathrm{g} \cdot \mathrm{m}^{-2}\right)\end{array}$} \\
\cline { 2 - 5 } & 2014.06 .03 & 2014.06 .18 & 2014.06 .03 & 2014.06 .18 \\
\hline & 117,6 & 137,1 & 6,7 & 49,7 \\
$\mathrm{PK}$ & 117,3 & 132,1 & 20,8 & 125,0 \\
$\mathrm{NK}$ & 71,6 & 80,4 & 4,9 & 40,3 \\
$\mathrm{NP}$ & 74,3 & 86,7 & 5,9 & 86,5 \\
$\mathrm{NPK}$ & 126,7 & 141,6 & 13,6 & 119,8 \\
\hline (4) $\mathrm{SzD}_{5 \%}$ & 44,7 & 50,3 & 6,0 & 37,7 \\
\hline
\end{tabular}

A kukorica 2-4 leveles fenológiai stádiumában a gyomok összes száraz biomassza tömege a kontroll, NK és NP kezelésekben átlagosan $5,8 \mathrm{~g} \cdot \mathrm{m}^{-2}$ volt, az NPK kezelésben ennek kétszeresét $\left(13,6 \mathrm{~g} \cdot \mathrm{m}^{-2}\right)$ mértük, míg a PK kezelésben mutatkozott a legmagasabb gyom biomasszaprodukció $\left(20,8 \mathrm{~g} \cdot \mathrm{m}^{-2}\right)(6$. táblázat $)$. A PK kezelés gyomflórájának kezdeti gyors növekedési üteme mérséklődött a kukorica 6-8 leveles fenológiai stádiumára. Az öt kezelés átlagában közel 
kilencszeres a gyom száraztömeg növekedési ráta a két időpont között, ezek közül a PK kezelésben csupán hatszoros volt (6. táblázat). A legnagyobb ütemü biomasszanövekedést az NP kezelésben mértünk, ahol ez a két vizsgálati időpont között tizenötszörös volt.

Mivel a két vizsgálati időpont között nem hullott csapadék, ezért a gyomok tápanyagfelvétele szempontjából az elérhető vízkészlet limitáló tényezővé válhatott. LEHOCZKY és munkatársai (2016) ezen időszak vízkészlet változását értékelő vizsgálatai nem mutattak ki szignifikáns eltérést a 0-80 $\mathrm{cm}$ mélységü talajszelvényben a kezelések között az első mintavételi időpontban. A második mintavételezés időpontjában is csupán a 20-30 cm-es talajmélységben volt szignifikáns a különbség a kontroll és az NPK között (LEHOCZKY et al., 2016). A második legkevesebb gyom biomasszatömeg növekedést (7,4-szeres változást, 6 . táblázat) a kontroll kezelés mutatta a két mintavételi idópont között, de itt a $\mathrm{N}$ mellett a P és $\mathrm{K}$ hatás is közrejátszhatott. Ezt magyarázhatja, hogy a növények csírázásához, megfelelő ütemü kezdeti fejlődéséhez elengedhetetlen a foszfor jelenléte (DEBRECZENI, 1979). BISCHOFF és MAHN (2000) szerint, a növények csírázást követő növekedése, fejlődése során a nitrogén jelentkezhet limitáló tényezőként, hiszen a biomassza képzéshez szükséges tápelemről van szó. A gyomnövények biomassza tömeg hányadosából (a két időpont közötti növekedési rátákból) valószínüsíthető, hogy kezdetben a foszfor, majd a második időpont idején a nitrogén hatása lehetett meghatározóbb. A száraz biomassza tömegek esetében a következő sorrendiséget állapítottuk meg a két vizsgálati időpont átlagát tekintve: $\mathrm{NK}<\emptyset<\mathrm{NP}<\mathrm{NPK}<\mathrm{PK}$.

\section{Következtetések}

A kukorica vetését követő ötödik és hetedik héten a vizsgált mintaterületeken jelentős gyomborítottságot tapasztaltunk, amely a kezelések átlagában $102 \mathrm{db} \mathrm{m}^{-2}$, majd $116 \mathrm{db} \mathrm{m}^{-2}$ volt. A mintavételek között eltelt két hét alatt az összes gyom egyedsürüség 14\%-kal nőtt, amely alapvetően három gyomfaj, a C. album, C. hybridum és $S$. halepense egyedszám-növekedésének következménye, tehát a kezelések sorrendje az egyedsürüség szerint mindkét időpontban a következöképpen alakult: $\mathrm{NK}<\mathrm{NP}<\mathrm{PK}<\varnothing<\mathrm{NPK}$.

$\mathrm{Az}$ első mintavétel alkalmával a gyomok összes földfeletti száraz biomasszatömege átlagosan $10,4 \mathrm{~g} \cdot \mathrm{m}^{-2}$ volt, két héttel később ennek nyolcszorosa, $84,3 \mathrm{~g} \cdot \mathrm{m}^{-2}$. A legkisebb arányú biomassza növekedés a kontroll és PK kezelésekben volt megfigyelhető, amely a nitrogén-utánpótlás hiányából adódó limitációnak tulajdonítható. A száraz biomassza tömeg esetében a két időpont átlagát tekintve a kezelések sorrendje a következő volt: $\mathrm{NK}<\emptyset<\mathrm{NP}<\mathrm{NPK}<\mathrm{PK}$.

$\mathrm{Az}$ egyes tápanyag kezelések hatását a gyomflóra összetételében, egyedsürüségében és biomassza tömegében is kimutattuk mindkét vizsgálati időpontban. A gyom egyedsürüség a kontroll és NPK, a biomassza tömeg pedig a PK és NPK kezelésekben statisztikailag is igazolhatóan nagyobb volt, a többi kezeléshez viszonyítva. 
A tápanyagok közül a foszfor jelenléte meghatározóbb lehetett a gyomflóra korai fenológiai stádiumában (2014.06.03.), majd a később (2014.06.18.) a nitrogén hatása válhatott egyre hangsúlyosabbá a gyomok növekedése, biomassza képzése szempontjából. Mindemellett a gyom száraz biomassza tömege, ill. annak a két vizsgált időpont közötti változása az eltérő tápanyagellátás, a mütrágyázás hatására kialakuló eltérő fajösszetételü gyomnövényzet (gyom-gyom kompetíció, ill. eltérő növekedési erélyü gyomfajok aránya), és a különböző összetételü gyomflóra kukoricával való kompetíciójának együttes hatására alakulhatott ki.

Továbbá a tápanyag kezelések hatása kifejeződött a gyomflóra dominancia viszonyaiban is. A kontroll, PK és NK kezelésekben az A. artemisiifolia és a $S$. halepense, az NPK kezelésben pedig a nitrofil $C$. album, $C$. hybridum és $D$. stramonium voltak a meghatározóak.

A fajösszetételt, a dominancia viszonyokat és a száraz biomassza tömeget tekintve az NP kezelés volt a legkiegyenlítettebb, az előforduló fajok közül egyik sem tudott 50\%-ot meghaladó részaránnyal jelen lenni.

\section{Összefoglalás}

A nagy területeken elterjedt gyomfajok erős alkalmazkodó képességgel rendelkeznek, így - különösen a kukorica korai fejlődési időszakában - a tápanyagokért és vízért folyó versenyben intenzív növekedésükkel a kultúrnövény fölé kerekedhetnek. A gyomflóra diverzitásának és gyomnövény-gyomnövény kapcsolatrendszernek a tápanyag-ellátottsággal összefüggésben történő vizsgálata kukorica állományban segítséget nyújthat a gyombiomassza produkció, a gyomflóra dominancia viszonyainak és a versengés várható hatásainak meghatározásában.

Kutatómunkánkat az MTA ATK TAKI nagyhörcsöki kísérleti telepén, mészlepedékes csernozjom talajon 2003-ban beállított trágyázási tartamkísérletben végeztük 2014-ben, öt kezelésben (kontroll, PK, NK, NP, NPK), hat ismétlésben a kukorica korai fejlődési szakaszaiban (BBCH 12-14 és BBCH 16-18). Öt és hét héttel a vetést követően vizsgáltuk a gyomflóra faji összetételét, a gyomnövények egyedsürüségét, dominancia viszonyait, továbbá mértük a gyomok földfeletti biomassza tömegét.

A mintaterületeken összesen 22 gyomfaj fordult elő. A gyomflóra diverzitásában a tápanyagkezelések szerint szignifikáns eltérések mutatkoztak. A kontroll (Ø), PK és NK kezelésekben az Ambrosia artemisiifolia L. és a Sorghum halepense (L.) Pers., az NP és NPK kezelésekben a Chenopodium album L., Chenopodium hybridum L. és Datura stramonium L. voltak a domináns fajok.

$\mathrm{Az}$ egyes gyomfajok egyedszáma és száraz biomassza tömege szignifikánsan változott a kezelések hatására. Az összes gyom egyedsürüség az első mintavételkor $71 \mathrm{db} \cdot \mathrm{m}^{-2}(\mathrm{NK})$ és $126 \mathrm{db} \cdot \mathrm{m}^{-2}$ (NPK) között volt. Két hét alatt átlagosan 14\%-kal nőtt meg: $80(\mathrm{NK})$ és $142 \mathrm{db} \cdot \mathrm{m}^{-2}$ (NPK) között volt az egy négyzetméterre eső egyedek száma. A kezelések egyedsürüség szerinti sorrendje nem módosult, mindkét vizsgálati időpontban a következőképpen alakult: $\mathrm{NK}<\mathrm{NP}<\mathrm{PK}<\varnothing<\mathrm{NPK}$.

A gyomok összes száraz biomassza tömege mindkét vizsgált időpontban az NK kezelésben volt a legkisebb (5 és $40 \mathrm{~g} \cdot \mathrm{m}^{-2}$ ), a PK kezelésben pedig a legnagyobb 
(21 és $125 \mathrm{~g} \cdot \mathrm{m}^{-2}$ ). A száraz biomasszatömeg szerint az NK, NP és kontroll kezelések között nem volt szignifikáns különbség, valamint a PK és NPK kezelés között sem. A két időpont átlaga alapján a kezelések sorrendje a következő volt: $\mathrm{NK}<\emptyset<\mathrm{NP}<\mathrm{NPK}<\mathrm{PK}$. Az egyes tápanyag kezelések hatását a gyomflóra egyedsürüségében és biomassza tömegében is kimutattuk.

Korai fenológiai fázisban a gyomok növekedését, ill. biomassza képzését az eltérő tápanyagellátás, a mütrágyázás hatására kialakuló eltérő fajösszetételü gyomnövényzet és a különböző összetételü gyomflóra kukoricával való kompetíciójának együttes hatása befolyásolta a legnagyobb mértékben.

Kulcsszavak: Ambrosia artemisiifolia L., Chenopodium album L., gyomflóra diverzitás, biomassza produkció, tápanyagellátottság

A kutatás az OTKA (K 105789 sz. pályázat) támogatásával valósult meg, amelyért a szerzők köszönetüket fejezik ki, valamint Dr. Csathó Péter tudományos tanácsadónak a trágyázási tartamkísérlethez való kapcsolódás lehetőségéért.

\section{Irodalom}

ANTAL J., 1987. Növénytermesztők zsebkönyve. Mezőgazdasági Kiadó, Budapest.

BERZSENYI, Z., BERÉNYI, GY., ÁRENDÁs, T. \& BÓNIS, P., 1993. Growth analysis of maize (Zea mays L.) in competition for different periods with barnyard grass [Echinochloa crus-galli (L.) BEAUV.] and redrot pigweed (Amaranthus retroflexus L.). Braunschweig. 8th EWRS Symposium. 107-115.

BISCHOFF, A. \& MAHN, E. G., 2000. The effects of nitrogen and diaspore availability on the regeneration of weed communities following extensification. Agriculture, Ecosystems and Environment. 77. 237-246.

BUZÁS I. (szerk.), 1979. A mütrágyázás irányelvei és üzemi számítási módszer. MÉM NAK, Budapest.

DEBRECZENI B., 1979. Kis agrokémiai útmutató. Mezőgazdasági Kiadó, Budapest

DoBSZAI-TóTH V. \& LEHOCZKY É., 2010. A fenyércirok (Sorghum halepense /L./ Pers.) jelentősége, biológiája, kártétele és a védekezés lehetőségei. Gyomnövények, gyomirtás: A Gyommentes Környezetért Alapítvány Kiadványa. 11. (1) 1-26.

HUNYADI K. (szerk.), 1988. Szántóföldi gyomnövények és biológiájuk. Mezőgazdasági Kiadó, Budapest.

Kádár I., Kismányoky T., Németh T., Pálmai O. \& SARKadi J., 1999. Tápanyag-gazdálkodásunk az ezredfordulón. Agrokémia és Talajtan. 48. (1-2) 193-202.

Kamuti, M., Mazsu, N., CSATHÓ, P. \& LehoczKy, É., 2015. Effects of nutrient supply on the weed flora composition in early growth stage of maize. Növénytermelés. 64. (Suppl.) 75-78.

KANG, Y., KHAN, S. \& MA, X., 2009. Climate change impacts on crop yield, crop water productivity and food security - A review. Progress in Natural Science. 19. $1665-1674$. 
Khan, M. A., KaKar, S., Marwat, K. B. \& Khan, I. A., 2013. Differential response of Zea mays $\mathrm{L}$. in relation to weed control and different macronutrient combinations. Sains Malaysiana. 42. (10) 1395-1401.

$\mathrm{KSH}$, 2016. Statisztikai tükör - A fontosabb növények vetésterülete, 2016. június 1. 2016. szeptember 27.

LÁSZTITY B. \& CSATHÓ P, 1994. A tartós NPK mütrágyázás hatások vizsgálata búza - kukorica dikultúrában. Növénytermelés 43. 157-167

LEHOCZKY, É., 2003. Effect of nitrogen fertilization on the biomass production and nutrient uptake of weeds in wheat. Proceedings of the $2^{\text {nd }}$ Alps-Adria Scientific Workshop. 209-213.

LEHOCZKY É., 2004a. A gyomnövények szerepe a talaj-növény rendszer tápanyagforgalmában. DSc Disszertáció. Keszthely.

LEHOCZKY É., 2004b. A növekvő adagú nitrogén ellátás hatása a parlagfü (Ambrosia artemisiifolia L.) növekedésére. Magyar Gyomkutatás és technológia. 5. (1) 32-41.

LEHOCZKY, É., REISINGER, P. \& KÖMÍVES, T., 2005. Loss of nutrients caused by excessive weediness at the early stage of maize vegetation period. Communications in Soil Science and Plant Analysis. 36. (4-6) 415-422.

LEHOCZKY, É. \& TóTH, V., 2005. Study on the biomass production of the $\mathrm{C}_{4}$ weed, Johnson grass (Sorghum halepense /L./ Pers.). Cereal Research Communications. 33. (1) 255-258.

LEHOCZKY, É., KISMÁNYOKY, A. \& NÉMETH, T., 2007. Effect of the soil tillage and $\mathrm{N}$-fertilization on the weediness of maize. Cereal Research Communications. 35. (2) 725-728.

LehoczKy, É., KAmuti, M., Mazsu, N., TAmÁs, J., SÁRINGer-KenYeres, D. \& GóLYA, G., 2014. Influence of NPK fertilization on weed flora in maize field. Agrokémia és Talajtan. 63. (1) 139-148.

LEHOCZKY, É., KAMUTI, M., MAZSU, N. \& SÁNDOR, R., 2016. Changes to soil water content and biomass yield under combined maize and maize-weed vegetation with different fertilization treatments in loam soil. Journal of Hydrology and Hydromechanics. 64. (2) 150-159.

LESKOVŠEK, R., Eler, K., BAtıČ, F. \& SimONČIČ, A., 2012. The influence of nitrogen, water and competition on the vegetative and reproductive growth of common ragweed (Ambrosia artemisiifolia L.). Plant Ecology. 213. (5) 769781.

MagurRan, A. E., 1988. Ecological diversity and its measurement. Princeton University Press, Princeton, New Jersey.

MSTAT, 1988. User's Guide to MSTAT-C: A Software Program for the Design, Management and Analysis of Agronomic Research Experiments. Michigan State University, East Lansing

NAGY, A. \& TAMÁs, J., 2013. Non-invasive water stress assessment methods in orchards. Communications in Soil Science and Plant Analysis. 44. 366-376.

NovÁK R., DAncza I., Szentey L. \& KARAmÁn J. (szerk.), 2011. Az ötödik országos gyomfelvételezés Magyarország szántóföldjein. Vidékfejlesztési Minisztérium, Budapest. 
Olesen, J. E., Trnka, M., Kersebaum, K. C., Skjelvåg, A. O., Seguin, B., Peltonen-Sainio, P., Rossi, F., Kozyra, J. \& Micale, F., 2011. Impacts and adaptation of European crop production systems to climate change. European Journal of Agronomy. 34. 96-112.

PÁlfai, I. \& Herceg, Á., 2012. Palfai Drought Index (PaDI) - Expansion of applicability of Hungarian PAI for Southeast Europe (SEE) region. LowerTisza District Water Directorate, Szeged.

PinKe, Gy., KARÁCSONY, P., CZúCZ, B. \& BotTA-DuKÁT, Z., 2011. Environmental and land-use variables determing the abundace of Ambrosia artemisiifolia in arable fields in Hungary. Preslia. 83. 219-235.

RAJCAN, I. \& SWANTON, C. J., 2001. Understanding maize-weed competition: resource competition, light quality and the whole plant. Field Crops Research. 71. 139-150.

RicZU, P., NAgY, A., LehocZKY, É. \& TAMÁs J., 2015. Precision weed detection using terrestrial laser scanning techniques. Communications in Soil Science and Plant Analysis. 46. (S1) 309-316.

Sengar, S. R. \& Sengar, K., 2015. Climate Change Effect on Crop Productivity. CRC Press. Taylor \& Francis Group, Boca Raton, USA

TAMÁs, J., NAGY, A. \& FEHÉR, J., 2015. Agricultural biomass monitoring on watersheds based on remotely sensed data. Water Science \& Technology. 72. (12) 2212-20.

TóTH, V. \& LEHOCZKY, É., 2006. Characteristics of development and nutrient uptake of Johnsohngrass (Sorghum halepense (L.) Pers) growing from seed during the first year. Journal of Plant Diseases and Protection. 20. 363-368.

UJVÁROSI M., 1973. Gyomnövények. Mezőgazdasági Kiadó, Budapest.

WEAVER, S. E. \& WARWICK, S. I., 1984. The biology of Canadian weeds. 64. Datura stramonium L. Canadian Journal of Plant Science. 64. 979-991.

Yeganehpoor, F., Salmasi, S. Z., Abedi, G., Samadiyan, F. \& Beyginiya, V., 2015. Effects of cover crops and weed management on crop yield. Journal of the Saudi Society of Agricultural Sciences. 14. 178-181.

YIN, L., CAI, Z. \& ZHONG, W., 2006. Changes in weed community diversity of maize crops due to long-term fertilization. Crop Protection. 25. 910-914. 


\title{
Examinations of weed flora and biomass production in a long-term fertilization experiment during the early phenological stages of maize
}

\author{
${ }^{1}$ N. Mazsu, ${ }^{1}$ M. KAMUtI, ${ }^{1}$ R. SÁndor, ${ }^{2}$ D. SZENTES and ${ }^{1}$ É. LeHoczKY \\ ${ }^{1}$ Institute for Soil Sciences and Agricultural Chemistry, Centre for Agricultural \\ Research, Hungarian Academy of Sciences, Budapest \\ ${ }^{2}$ Directorate of Plant Protection, Soil Conservation and Agri-enviroment, National Food \\ Chain Safety Office, Budapest
}

\begin{abstract}
Summary
The weed species that are currently widespread have great adaptability, and are thus able to compete strongly for nutrients and water, exhibiting intensive growth and suppressing the cultivated plants, especially during the early phenological stages of maize. Investigations on the weed diversity and weed-weed relationships in maize fields in terms of nutrient supplies could help to determine the weed biomass production, the dominance of various weed species and the expected effects of competition.

The effect of different nutrient supplies on the weed infestation of maize was studied in 2014 in a long-term fertilization experiment set up in 2003 on a FAO Calcaric Phaeosem soil at the Experimental Station of the Institute for Soil Sciences and Agricultural Chemistry (MTA ATK) in Nagyhörcsök, Hungary. The species composition of the weed flora, the weed plant density, the dominance of the weed species and the aboveground weed biomass were studied in six replications in five treatments (control, PK, NK, NP, NPK) five (BBCH 12-14) and seven (BBCH 1618) weeks after sowing.

A total of 22 weed species occurred in the different treatments. The diversity of the weed species differed significantly in the individual treatments. Ambrosia artemisiifolia L. and Sorghum halepense (L.) Pers were the dominant species in the control, PK and NK treatments, and Chenopodium album L., Chenopodium hybridum L. and Datura stramonium L. on the NP and NPK plots. The weed diversity and the aboveground biomass of each weed species changed significantly in response to the treatments. At the first sampling date, the total weed density ranged from 71 plant $\cdot \mathrm{m}^{-2}$ (NK) to 126 plant $\cdot \mathrm{m}^{-2}$ (NPK). Two weeks later, the total weed density increased by $14 \%$ on average, ranging from $80 \mathrm{plant} \cdot \mathrm{m}^{-2}$ (NK) to 142 plant $\cdot \mathrm{m}^{-2}$ (NPK). The order of the treatments in terms of weed density was $\mathrm{NK}<\mathrm{NP}<\mathrm{PK}<\emptyset<\mathrm{NPK}$ in both the phenophases.

The total dry aboveground weed biomass was lowest in the NK treatment (5 and $\left.40 \mathrm{~g} \cdot \mathrm{m}^{-2}\right)$ and highest in the PK treatment $\left(21\right.$ and $\left.125 \mathrm{~g} \cdot \mathrm{m}^{-2}\right)$ at both sampling dates. There was no significant difference in weed biomass production between the NK, NP and control treatments or between the PK and NPK treatments. Averaged over the two sampling dates the order of the treatments was the following: $\mathrm{NK}<\varnothing<\mathrm{NP}<\mathrm{NPK}<\mathrm{PK}$. The effect of the nutrient treatments was also detected in the total weed density and biomass.
\end{abstract}


In the early phenological stages, weed growth and biomass production were influenced to the greatest extent by the simultaneous effect of different macronutrient supplies, the diverse species composition of the weed population in response to mineral fertilisation, and to the competition of the weed flora with maize.

Key words: Ambrosia artemisiifolia L., Chenopodium album L., weed flora diversity, biomass production, nutrient supplies

Table 1. Chemical soil properties on the experimental area in each treatment (Ø, PK, NK, NP and NPK), Nagyhörcsök, 2013. (1) Treatment. (2) Organic matter.

(3) Salinity. (4) $\mathrm{LSD}_{5 \%}$. Note: n.s. = non-significant $(\mathrm{p}<0.05)$

Table 2. List of weed species in order of frequency, averaged over the treatments (, PK, NK, NP and NPK) during the early phenological stages of maize (BBCH12-14 and BBCH16-18), Nagyhörcsök, $3^{\text {rd }}$ and $18^{\text {th }}$ June 2014. (1) Weed species. (2) Plant family code (EPPO). (3) Life form. (4) Frequency of weed species (on $3^{\text {rd }}$ and $18^{\text {th }}$ June). (5) Mean. Note: Life forms of the weed species as classified by Ujvárosi (1973)

Table 3. Order of dominance of the weed species in the different treatments $(\varnothing$, PK, NK, NP and NPK) based on the average dominance index of the two sampling dates, Nagyhörcsök, $3^{\text {rd }}$ and $18^{\text {th }}$ June 2014. (1) Weed species. (2) Mean. (3) Other weed species. (4) Total.

Table 4. Dry aboveground weed biomass $\left(\mathrm{g} \cdot \mathrm{m}^{-2}\right)$ in the different treatments $(\varnothing$, PK, NK, NP and NPK) and averaged over the treatments, Nagyhörcsök, $3^{\text {rd }}$ June 2014. (1) Weed species. (2) Dry biomass $\left(\mathrm{g} \cdot \mathrm{m}^{-2}\right)$. (3) $\mathrm{LSD}_{5 \%}$. Note: $\mathrm{n} . \mathrm{s} .=$ nonsignificant $(\mathrm{p}<0.05)$

Table 5. Dry weed biomass $\left(\mathrm{g} \cdot \mathrm{m}^{-2}\right)$ in the different treatments $(\varnothing, \mathrm{PK}, \mathrm{NK}, \mathrm{NP}$ and NPK) and averaged over the treatments, Nagyhörcsök, $18^{\text {th }}$ June 2014. (1) Weed species. (2) Dry biomass $\left(\mathrm{g} \cdot \mathrm{m}^{-2}\right)$. (3) $\mathrm{LSD}_{5 \%}$. Note: $\mathrm{n} . \mathrm{s} .=$ non-significant $(\mathrm{p}<0.05)$

Table 6. Cumulated weed density $\left(\right.$ plant $\left.\cdot \mathrm{m}^{-2}\right)$ and dry biomass $\left(\mathrm{g} \cdot \mathrm{m}^{-2}\right)$ in each treatment (Ø, PK, NK, NP and NPK), Nagyhörcsök, $3^{\text {rd }}$ and $18^{\text {th }}$ June 2014. (1) Treatment. (2) Weed density (plant $\left.\cdot \mathrm{m}^{-2}\right)$. (3) Dry weed biomass $\left(\mathrm{g} \cdot \mathrm{m}^{-2}\right)$. (4) $\mathrm{LSD}_{5 \%}$.

Figure 1. Daily mean precipitation sum $(\mathrm{mm})$ and daily mean temperature $\left({ }^{\circ} \mathrm{C}\right)$ from $30^{\text {th }}$ April to $18^{\text {th }}$ June 2014 and average values for the same period between 1967 and 2012, Nagyhörcsök. Note: Black bar: daily mean precipitation, 19672012, shaded bar: daily precipitation, 2014. Solid line: daily mean temperature, 1967-2012, dashed line: daily mean temperature, 2014.

Figure 2. Density of weed species (plant $\left.\mathrm{m}^{-2}\right)$ in different treatments $(\varnothing, \mathrm{PK}$, NK, NP and NPK), averaged over the sampling dates ( $3^{\text {rd }}$ June and $18^{\text {th }}$ June 2014), Nagyhörcsök $(\mathrm{n}=12)$. For weed species, see Table 2. Note: * significant differences $(\mathrm{p}<0.05)$ between treatments. 